\title{
HINDRANCE AND BENEFITS TO GREEN BUILDING IMPLEMENTATION: EVIDENCE FROM BENIN CITY, NIGERIA
}

\author{
Ernest O. Alohan \\ Department of Estate Management, Faculty of Environmental Sciences \\ University of Benin P.M.B 1154 \\ e-mail:ernnygentle2009@gmail.com

\begin{abstract}
Abiodun Kolawole Oyetunji
Lancaster Environment Centre, Lancaster University, UK, LA1 4YQ

Department of Estate Management, Faculty of Environmental Sciences

University of Benin P.M.B 1154

e-mail:a.oyetunji@lancaster.ac.uk; abiodun.oyetunji@uniben.edu
\end{abstract}

\begin{abstract}
The clamor for sustainable development and reduction of greenhouse gases led to the green concept which, in recent times, has gained significant momentum. To encourage the widespread development of green buildings, an understanding of the awareness, benefits, and hindrances for their adoption is necessary.

This is relevant now that concerns over climate change have led to an increasing global demand for sustainability within the built environment. While the discourse is still rather muted in Nigeria, this study will contribute to the ongoing effort to raise public awareness regarding green building development and the potential benefits by evaluating the opinion of professionals regarding the subject matter.

Structured questionnaires were distributed among five different professions in the built environment and information sourced includes the level/mode of awareness, benefits and bottleneck, and support for its development.

The survey results showed that $43.48 \%$ of the professionals advocated for the development of green construction in Nigeria. The benefits and bottlenecks were ranked according to their perceived importance. The study recommends public enlightenment on green education, enforcement of mandatory training, formulation and implementation of policies directed towards green building acceptability. This will help promote and protect the built environment, and reduce health hazards posed by conventional development.
\end{abstract}

Keywords: awareness, built environment, green building, greenhouse gas, sustainable development.

JEL Classification: Q01, R31.

Citation: Alohan, E. O., \& Oyetunji, A. K. (2021). Hindrance and benefits to green building implementation: evidence from Benin City, Nigeria. Real Estate Management and Valuation, 29(3), 65-76.

DOI: https://doi.org/10.2478/remav-2021-0022

\section{Introduction}

In recent times, climate change has been a major source of concern all over the world. The discharge of greenhouse gasses was identified as a contributory factor to climate change. Gas flaring, motor vehicle emissions, bush burning, industrial processes, land-use changes, and the transport and construction 


\section{S sciendo}

sector, amongst others, have been important sources of greenhouse gas emissions throughout the world over the years. The climate change effect with its accompanying problems and challenges generated the need and clamor for a sustainable environment, which has gained significant momentum worldwide in recent times, particularly in developed nations.

Greenhouse gases (GHGs), due to natural and human activities, are believed to be responsible for about one-third of total anthropogenic carbon dioxide $\left(\mathrm{CO}_{2}\right)$ emitted into the atmosphere (Aggarwal \& Markanda, 2013). Energy consumption is on the increase due to population growth, urbanization, and globalization through information technology and related businesses in India and China, with more than $41 \%$ of energy consumption accounted for by buildings in developed countries (Ramesh \& Emran, 2013; Tathagat \& Dod, 2015). To ameliorate the inefficiency of conventional buildings when it comes to energy consumption, waste generation, water conservation, land use efficiency, and reduction in greenhouse gases, the green concept - green buildings - has emerged (Ramesh \& Emran, 2013; Tathagat \& Dod, 2015).

Gunnell (2009) also stated that the negative environmental effect of property development and rising energy prices alongside persistent water shortages have led to the emerging concept of green buildings, which are designed to be energy and water efficient, use non-hazardous materials and provide healthy productive environments. This is why Darko et al., (2017) submitted that the concept of green building has gradually been adopted to minimize the negative impacts of the construction industry on the environment, economy, and society.

Despite the promotional efforts towards green building, the emissions and waste generated by buildings continue unabatedly. Matthew et al., (2019), while examining the effects of manufacturing industries and construction emissions on health conditions, asserted that human activities release gaseous emissions that, in turn, affect human health. The study by Matthew et al., (2019) recommended that the government should formulate environmental policies to mitigate the adverse effect of carbon dioxide emissions and increase public health expenditure to adequately take care of the health of the individuals. The long-term effect of greenhouse gases on the aggregate health of individuals revealed that a one percent increase in greenhouse gas emissions can reduce life expectancy by $0.00422 \%$ (Matthew et al., 2018) with an increased mortality rate of $14.6 \%$. It was therefore concluded that health outcomes can be improved by, amongst others, reducing the emissions of carbon dioxide through the reduction of deforestation and conservation of land, controlling wildfires, adopting better methods of combusting residues of crops, and the effective use of energy by forest dwellers.

Construction activities in developing countries consume resources, cause land degradation, loss of habitats, as well as air and water pollution, as well as involving high energy usage and producing approximately 23-40\% of the world's greenhouse gas emissions (Ofori, 2012; Gunnell, 2009). Giwa et al., (2017) provided an inventory of the emissions of greenhouse gases released into the atmosphere through the combustion of fossil fuels from 1980 to 2014. It was revealed that gasoline consumption accounted for $71.23 \%$ of the total amount of greenhouse gases with $\mathrm{CO}^{2}$ making up $98.72 \%$. The author opined that poor indoor and outdoor air quality occasioned by the burning of these fuels contributed significantly to public health and environmental problems. It was suggested that the national policy on emissions should be reformulated and enforced, and the problems beclouding electrical power supply must be resolved to reduce the incidence of using generators in order to cut down on greenhouse gas emissions.

The literature review revealed that green building technology is increasingly gaining recognition and acceptance in the construction industry. This has led to the development of green building guidelines in most developed countries. They include Leadership in Energy and Environmental Design (LEED) developed by U.S. Green Building Council (USGBC), Building Research Establishment Environmental Assessment Method (BREEAM) introduced in the U.K. by the Building Research Establishment (BRE) and the Comprehensive Assessment System for Building Environmental Efficiency (CASBEE), which was introduced by the Japan Sustainable Building Consortium (JSBC) (Potbhare et al., 2009). The promotion and adoption of green buildings revealed that several strategies can be adopted for the implementation. For instance, Chan et al., (2017) asserted that finance, marketbased incentives, government policies and regulations, availability of better information on cost and benefits, green rating and labelling are strategies that can enhance the promotion of the adoption of green building technology in the construction industry.

The effects of rising energy prices and environmental challenges are already apparent in 
developing countries. Therefore, it is still an unraveled mystery that green building initiatives and technologies are yet to fully gain prominence within the construction industry in Nigeria when compared to its developing nation counterparts. This leads to questions which call for urgent answers. For instance, "can it be concluded that there is limited awareness regarding the concept among the stakeholder's in the building industry, is it that their perception to the benefits inherent in the green initiatives is unclear, or their perception about the hindrance to its implementation makes them shy away from its inclusion into the building sector". As a result of these unanswered questions, this paper seeks to investigate the awareness and knowledge of the barriers and benefits of sustainable construction using green building technology. This was done by examining the opinion of the stakeholders involved in the construction and real estate market in Nigeria, using Benin City as a representative case.

\section{Literature review}

As the saying goes, necessity is the mother of inventions. The clamor for a sustainable environment due to the emission of a large volume of pollutants and greenhouse gases and the energy inefficiency associated with conventional buildings gave room for the emergence of the green building initiative. In Nigeria, Edeoja and Edeoja (2015) adopted a three case study approach of construction firms to ascertain carbon emission management in the construction industry. This is done to estimate the energy consumption and the direct emissions of carbon as a result of construction activities. The study revealed that there was no policy regulating greenhouse gases within the various organizations. This, according to the authors, reflects the general attitude towards environmental/carbon emission matters in Nigeria. Edeoja and Edeoja (2015) claimed that proper documentation of energy consumption, types, and the amount spent will enhance carbon emission management and monitoring. Sagheb et al., (2011) suggested that in the construction of a conventional building, materials such as stone, steel, concrete, and Gypsum plaster have the highest energy consumption among other building materials. These materials can be replaced by those with low carbon emissions, such as recyclable, eco-friendly building materials, vernacular architecture, and locally available materials.

Green building, which is also referred to as "high-performance building", "sustainable building", "intelligent building" or "green construction (architecture)," has varied definitions depending on how it is viewed. According to Alam and Haque (2016), it was defined as "a building whose construction and an operational lifetime assure the healthiest possible environment while representing the most efficient and least disruptive use of land, water, energy and resources". Okafor (2016) defined it as "a structure that utilizes a process that is environmentally responsible and resource-efficient throughout its life-cycle from siting to design, construction, operation, maintenance, renovation, and demolition. For purposes of this study, green building development refers to high-performance property that meets the occupier's and user's needs, satisfies their comfort and well-being, as well as being environmentally friendly without impacting human health.

A green building helps in the reduction of operating costs, such as energy and water as a result of the green features and facilities that are integrated into it. Another striking attribute of a green building is the healthy environment that it provides throughout the lifetime of its construction. Tathagat and Dod (2015) opined that green buildings are concerned with the provision of comfort for humans, safety, productivity and the extension of the lifespan of natural resources, hence, they are designed for occupant comfort, resource efficiency, environmental responsibility, wellbeing of the people. Green buildings as asserted by Ramesh and Emran (2013) help to reduce the demand for new power plants as they reduce the overall demand for energy, resulting in the reduction of greenhouse gas (GHG) emissions. Ishan et al., (2014) also opined that it was fundamental to reduce greenhouse gas emissions which are produced by conventional buildings to slow down the pace of global climate change. This new phenomenon is now widely accepted and has been promoted in the US (Cryer et al., 2006).

Studies have shown that the construction of conventional buildings promotes the destruction of non-renewable natural resources and results in increased environmental impact due to the extraction of building materials and construction industry waste. In addition to this, a large amount of energy is required for all of these processes, contributing to global ecological degradation and greenhouse gas emission. Ishan, et al., (2014) stated that buildings could be associated with greenhouse gases through construction and demolition waste as well as the extraction and manufacturing of building materials. Energy expended for heating and powering buildings is derived largely from the burning of fossil fuels, which generate carbon dioxide $\left(\mathrm{CO}_{2}\right)$. Contrary to conventional types of buildings, the green or 
intelligent building minimizes the use of non-renewable resources and promotes the use of renewable natural resources in order to sustain our future. Mehta et al. (2014) argued that, in sustaining the urban future, the option was to adopt the green concept by building in ways that improve the health of the ecosystem, protect natural resources, and reduce environmental damages. Today, many developed nations of the world like Germany, USA, UK, Korea, China have fully evolved to using the green concept in their construction industry, whereas some countries are, for some reasons, either ignoring or delaying the acceptance of the concept (Dalibi, et al., 2017).

In Nigeria, conventional buildings are still very dominant and will continue to be in years to come. The building industry is still more focused on the development of conventional buildings. However, very few buildings try to introduce some element of green design in their construction, through the introduction of solar panels as an alternative to an electric power supply to provide energy for cooling, lighting and providing power for their equipment and installing other energy-efficient fixtures to increase the level of insulation in the building. With the advancements in technology, these buildings can be retrofitted to increase efficiency, environmental responsibility, and the wellbeing of the occupant. In civil engineering, retrofitting is referred to as the addition of new technology or features into an old structure to improve efficiency. It tends to create a high-performance building from the old or formal structure.

Green buildings have been found to promote well-being, with great benefit to human health and the community, improving environmental quality, reducing the use of energy and water, and improving life-cycle economic performance (Durmus-Pedini \& Ashuri, 2010; Ramesh \& Emran, 2013). Research on green buildings revealed that such buildings had fewer carbon emissions, higher occupant satisfaction, use less energy and water and are thus characterized by lower aggregate maintenance costs. (Durmus-Pedini \& Ashuri, 2010). They also opined that other studies showed that green buildings with LEED-EB compliance had operational cost savings over the operational costs of traditional buildings. Studies have also shown that green building life cycle yields benefit more through energy and other operational cost savings when compared to traditional buildings. For instance, Durmus-Pedini and Ashuri (2010) asserted that an investment of an extra 2\% of the construction cost will yield over ten times the initial investment through energy and other operational cost savings over the life cycle of the building. Durmus-Pedini and Ashuri (2010) summarized the benefits of a green building under five headings, i.e. environmental, health and community, financial, market and industry benefits. Ishan et al, (2014) stated that the economic and environmental performance of buildings can be maximized through the successful implementation of green building strategies. The authors also opined that green buildings have benefits, which they categorized as an environmental, economic, and social benefit. Ramesh and Emran (2013) listed the benefits of green buildings, as shown in Table 1.

Table 1

Benefits from Green Buildings

\begin{tabular}{|c|c|c|c|}
\hline Real Estate Value & $\begin{array}{c}\text { Sustainable Asset } \\
\text { Management }\end{array}$ & $\begin{array}{l}\text { Environmental } \\
\text { Effects }\end{array}$ & Ultimate Effects \\
\hline $\begin{array}{l}\text { - Improved indoor } \\
\text { air quality, } \\
\text { productivity and } \\
\text { living satisfaction } \\
\text { - Advance } \\
\text { capabilities to deal } \\
\text { with “Chun” } \\
\text { (occupant } \\
\text { turnover/ } \\
\text { evolving mission) } \\
\text { - Reduced future } \\
\text { capital } \\
\text { expenditures } \\
\text { - Higher resale } \\
\text { value or lease rates }\end{array}$ & $\begin{array}{l}\text { - Optimized asset } \\
\text { management and } \\
\text { better space } \\
\text { utilization } \\
\text { - Reduced cost for } \\
\text { alterations } \\
\text { - Reduced capital costs } \\
\text { including cabling, } \\
\text { administration, } \\
\text { training and project } \\
\text { management }\end{array}$ & $\begin{array}{l}\text { - Reduced } \\
\text { greenhouse gas } \\
\text { and carbon } \\
\text { dioxide emissions } \\
\text { - Reduced energy } \\
\text { and water usage } \\
\text { - Reduced } \\
\text { construction and } \\
\text { demolition waste } \\
\text { - Leverage } \\
\text { renewable energy } \\
\text { technologies }\end{array}$ & $\begin{array}{l}\text { - Healthier and more } \\
\text { comfortable building } \\
\text { environment } \\
\text { - Improved long-term } \\
\text { economic } \\
\text { performance } \\
\text { - Sustainability i.e. } \\
\text { easier to maintain } \\
\text { and built to last } \\
\text { - More competitive: } \\
\text { "best of breed" } \\
\text { procurement } \\
\text { - More efficient use of } \\
\text { O\&M }\end{array}$ \\
\hline
\end{tabular}

Source: Ramesh \& Emran (20130. 
Several factors that limit and hinder the growth and adoption of green developments in different countries have been identified. For instance, in China, Wu et al. (2019) identified 24 potential barriers that hinder green building development, whereas Zhang et al (2011) also established that higher cost is a limiting factor to its implementation. Williams and Dair (2007) claimed that, in England, high perceived costs, lack of consideration and inadequate expertise are the limiting factors. Love et al. (2012) pointed out that the key barriers to green building development in Australia are the lack of relevant knowledge and government incentives, while in Hong Kong, Lam et al. (2009) established that limited availability of reliable suppliers, delays and additional costs involved are the barriers hindering the development of green buildings. Masrom et al. (2017) discovered that higher costs and the lack of green consciousness are barriers in Malaysia, whereas in Ghana, Chan et al. (2018) revealed that the barriers to green building development can be grouped into five categories.

In South Africa, Simpeh and Smallwood $(2015,2018)$ argued that capacity barriers, cultural and social resistance, lack of incentives for its promotion, inadequate cost data, a limited range of green products and materials, delays in obtaining permits and certification and inadequate information about the financial and economic benefits and opportunities are the main barriers to green development. Dalibi et al. (2017) highlighted 10 factors responsible for hindering the development of green buildings. These include the perception of the concept being expensive; the unavailability of local materials and other components as well as the high cost of imported green building materials; divergent interests and views of success factors and success criteria of green building developments among stakeholders; lack of green building cost data and other performance-related data; lack of data for using green building assessment systems; green building with its associated risks; green building technical know-how; cultural, economic, social and technical barriers; green building awareness and the lack of a local or a single standard green building assessment system. Similarly, Uwazie, et al. (2015) identified the major challenges confronting the green economy to include developmental, energy and environmental and data challenges. Dahiru et al. (2014) also identified the problems facing the practice of green building implementation to include an unsupportive environment, an uncertain economic environment, technological barriers, the dearth of integrated research and the lack of interest in the issue of sustainability.

\section{Data and Methods}

This paper investigates the level of awareness, benefits and hindrances to the adoption of the green concept by stakeholders in the Nigerian built environment. This is achieved with a special focus on five prominent land-related professions in the construction industry in Benin City, Nigeria. To collate the primary data in response to the research questions, a structured questionnaire was used as a tool for gauging the respondents' perception regarding green building initiatives. Relevant information was sourced from professionals (estate surveyors, quantity surveyors, land surveyors, architects and builders) in the built environment within the study area.

The above-listed professionals were chosen based on their presence within the study location. They were deemed suitable to complete the questionnaire because of their experience, exposure and involvement in the construction sector, thereby contributing to the growth of the economy. The respondents were selected using purposive sampling techniques. A comprehensive sampling frame for the participants could not be ascertained, hence the sample selection was purposely chosen from the available register in the state secretariat of professionals in the study area. The purposive sampling technique adopted involves identifying and selecting participants that are knowledgeable about or experienced with the phenomenon of interest (Cresswell \& Plano Clark, 2011). In addition to knowledge and experience, the availability and willingness to participate, and the ability to communicate experiences and opinions in an articulate, expressive, and reflective manner were also considered (Bernard, 2002). Although there are challenges in identifying and applying an appropriate purposive sampling strategy, this however does not affect the outcomes of the research. This element of bias was eliminated using the judgement of the researcher for selecting the units of investigation. The participants are then selected according to the needs and requirements of the study.

A structured questionnaire was administered to these professionals between October 2019 to April 2020 using a face-to-face approach as the responses were obtained before the nation was shut down due to the coronavirus pandemic that has been ravaging the world. The research data collected were analyzed using the SPSS statistical package. A five-point Likert scale ranging from 5 to 1 in 
descending order was adopted for questions on the perceived benefits and hindrances to green building development. Responses from the Likert scale were computed for mean ratings of each factor following their level of importance as perceived by the respondents.

The mean scores were then ranked according to their weighted level of importance. The decision point for the 5-point Likert scale used in the study was structured according to Ojo et al. (2018). A total of 184 questionnaires were distributed, out of which only $161(87.50 \%)$ were returned and considered valid for the study. Table 2 shows a breakdown of the questionnaires administered and their corresponding retrieval.

Table 2

Questionnaire Administration

\begin{tabular}{llcc}
\hline \multirow{2}{*}{ S/No. } & \multicolumn{2}{|}{ Professionals } & \multicolumn{2}{c}{ Questionnaire } \\
\cline { 3 - 4 } & & Distribution & Retrieval \\
\hline 1. & Estate Surveyors \& Valuers & $51(100.00 \%)$ & $48(97.12 \%)$ \\
\hline 2 & Quantity Surveyors & $30(100.00 \%)$ & $23(76.67 \%)$ \\
\hline 3 & Land surveyors & $50(100.00 \%)$ & $44(88.00 \%)$ \\
\hline 4 & Architects & $30(100.00 \%)$ & $27(90.00 \%)$ \\
\hline 5 & Building Engineers & $23(100.00 \%)$ & $19(82.61 \%)$ \\
\cline { 2 - 4 } & \multicolumn{1}{c}{ Total } & $\mathbf{1 8 4}(\mathbf{1 0 0 . 0 0 \% )}$ & $\mathbf{1 6 1 ( 8 7 . 5 0 \% )}$ \\
\hline
\end{tabular}

Source: Author's survey.

\section{Results and Discussion}

This section of the paper is concerned with the results and findings that emanates from the survey. It shows the perception of the respondents as well as their awareness and knowledge regarding the subject matter.

To gain an insight into the level of awareness among the professionals about the concept of green buildings, the respondent's opinion was sought regarding their awareness and knowledge of green building, the medium that creates more awareness for them, their ability to discern between conventional and green building technologies, whether they advocate for green building, and whether any policy on green building exists in Nigeria. Based on their experience and level of understanding of the subject, and as revealed in Table 3, a total of $61.49 \%$ of respondents considered themselves aware of the concept of green initiatives. This result suggests that, in order to be more aware, there is the need to sensitize the professionals in the location under study. This is because the percentage of awareness despite the age of information technology is still lower among some sets of professionals within the built environment.

Regarding the medium by which awareness is raised, it was observed that only $24.84 \%$ of the respondents were made aware through media, whereas $34.78 \%$ declined to give a response. The indication of this response rate shows that green building initiatives are not well communicated among professionals within the study area. Formal knowledge and awareness for professionals in the built environment discipline is an important mechanism for developing green building knowledge and skills. Hence, it can be concluded that the poor culture of green building within the country is due to inadequate communication techniques for the sensitization process.

Table 3

Respondents opinion about the green building initiatives

\begin{tabular}{|c|c|c|c|c|c|c|c|}
\hline \multirow[t]{2}{*}{ Features } & \multirow[t]{2}{*}{ Response } & $\begin{array}{c}\text { Estate } \\
\text { Surveyors }\end{array}$ & $\begin{array}{c}\text { Quantity } \\
\text { Surveyors }\end{array}$ & $\begin{array}{c}\text { Land } \\
\text { Surveyors }\end{array}$ & Architects & Builders & Total \\
\hline & & $F(\%)$ & $F(\%)$ & $\mathrm{F}(\%)$ & $F(\%)$ & $F(\%)$ & $F(\%)$ \\
\hline \multirow{4}{*}{$\begin{array}{l}\text { Level of } \\
\text { awareness }\end{array}$} & Aware & $26(54.17)$ & 11(47.82) & $24(54.55)$ & $24(88.89)$ & 14(73.68) & 99(61.49) \\
\hline & Not aware & $16(33.33)$ & $6(26.09)$ & $11(25.00)$ & $3(11.11)$ & $5(26.32)$ & $41(25.47)$ \\
\hline & No response & $6(12.50)$ & $6(26.09)$ & $9(20.45)$ & $0(0.00)$ & $0(0.00)$ & $21(13.04)$ \\
\hline & Total & $48(100.00)$ & $23(100.00)$ & $44(100.00)$ & $27(100.00)$ & 19(100.00) & $161(100.00)$ \\
\hline \multirow{3}{*}{$\begin{array}{l}\text { Medium of } \\
\text { awareness }\end{array}$} & Media & $8(16.67)$ & $4(17.39)$ & $16(36.36)$ & $9(33.33)$ & $3(15.79)$ & $40(24.84)$ \\
\hline & MCPD & $6(12.50)$ & $3(13.05)$ & $0(0.00)$ & $0(0.00)$ & $4(21.05)$ & $13(8.08)$ \\
\hline & $\begin{array}{l}\text { Other } \\
\text { professionals }\end{array}$ & 18.75) & $(0.00)$ & (9.10) & 13(48.15) & (0.00) & $26(16.15)$ \\
\hline
\end{tabular}




\section{S sciendo}

\begin{tabular}{lllccccc}
\hline & $\begin{array}{l}\text { Other } \\
\text { sources }\end{array}$ & \multirow{2}{*}{$10(20.83)$} & $4(17.39)$ & $5(11.36)$ & $0(0.00)$ & $7(36.84)$ & $26(16.15)$ \\
\cline { 2 - 8 } & No response & $15(31.25)$ & $12(52.17)$ & $19(43.18)$ & $5(18.52)$ & $5(26.32)$ & $56(34.78)$ \\
\cline { 2 - 7 } & Total & $\mathbf{4 8 ( 1 0 0 . 0 0 )}$ & $\mathbf{2 3 ( 1 0 0 . 0 0 )}$ & $\mathbf{4 4 ( 1 0 0 . 0 0 )}$ & $\mathbf{2 7 ( 1 0 0 . 0 0 )}$ & $\mathbf{1 9 ( 1 0 0 . 0 0 )}$ & $\mathbf{1 6 1 ( 1 0 0 . 0 0 )}$ \\
\hline $\begin{array}{l}\text { Ability to } \\
\text { differentiate } \\
\text { between }\end{array}$ & No & $18(37.50)$ & $4(17.39)$ & $7(15.91)$ & $17(62.97)$ & $13(68.42)$ & $59(36.65)$ \\
\cline { 2 - 7 } & No response & $16(33.33)$ & $12(52.18)$ & $23(52.27)$ & $7(25.92)$ & $4(21.05)$ & $62(38.51)$ \\
\cline { 2 - 7 }
\end{tabular}

green and

conventional

\begin{tabular}{|c|c|c|c|c|c|c|c|}
\hline buildings & Total & $48(100.00)$ & $23(100.00)$ & $44(100.00)$ & $27(100.00)$ & $19(100.00)$ & $161(100.00)$ \\
\hline \multirow{4}{*}{$\begin{array}{l}\text { Advocate for } \\
\text { green } \\
\text { building in } \\
\text { Nigeria }\end{array}$} & Yes & $21(43.75)$ & $8(34.78)$ & $8(18.18)$ & $23(85.19)$ & $10(52.63)$ & $70(43.48)$ \\
\hline & No & $12(25.00)$ & $0(0.00)$ & $7(15.91)$ & $0(0.00)$ & $4(21.05)$ & $23(14.29)$ \\
\hline & No response & $15(31.25)$ & $15(65.22)$ & $29(65.91)$ & $4(14.81)$ & $5(26.32)$ & $68(42.23)$ \\
\hline & Total & $48(100.00)$ & $23(100.00)$ & $44(100.00)$ & $27(100.00)$ & $19(100.00)$ & $161(100.00)$ \\
\hline \multirow{3}{*}{$\begin{array}{l}\text { Awareness } \\
\text { of policy } \\
\text { documents }\end{array}$} & Yes & $3(6.25)$ & $0(0.00)$ & $0(0.00)$ & $6(22.22)$ & $0(0.00)$ & $9(5.59)$ \\
\hline & No & $45(93.73)$ & 17(73.91) & $44(100.00)$ & $14(51.85)$ & $19(100.00)$ & $139(86.35)$ \\
\hline & No response & $0(0.00)$ & $6(26.09)$ & $0(0.00)$ & $7(25.93)$ & $0(0.00)$ & $13(8.08)$ \\
\hline
\end{tabular}

on green

building in

Nigeria

Total

$48(100.00) \quad 23(100.00) \quad 44(100.00)$

27(100.00)

19(100.00)

$161(100)$

Source: Author's survey.

The responses on the ability to differentiate between conventional and green building revealed that $38.51 \%$ of the respondents could not easily differentiate between the two forms of construction. The implication of this is that the level of development regarding green construction will be greatly affected, since the professional's level of discernment is very low. When it comes to advocacy for green building construction, it was observed that $43.48 \%$ of the respondents advocate for the promotion of green building. This depicts that the professionals want to improve their knowledge on the subject. This is because broadening their horizon will aid in the successful delivery of sustainable projects. Regarding their awareness as to policy documents on green building in Nigeria, $86.35 \%$ of the respondents' opinions suggest that there is still a void to be filled by the government. This is because the program of housing delivery is not fully communicated, as a bottleneck and bureaucracy are present. Hence the rationale for the existence of a viable policy document to prioritize the development of green construction.

The benefits of green building developments according to the professionals' perspectives have been summarized in Table 4. Respondents who participated in this study were asked to rank their level of agreement regarding the benefits of implementing green building. According to every professional involved, enhancement of the comfort and health of occupant was recognized as the most important benefit of green building development by the estate surveyors. The quantity surveyors claimed that reduced aggregate future capital and maintenance costs is the most important benefit, while the land surveyors agreed to the creation of new opportunities for other industries. To the architects, improved internal air quality, productivity and the occupants' satisfaction were found to be most important, whereas according to the builders, the promotion of technological exchange across borders was the benefit of green building perceived to be the most important.

To provide a general picture of the situation, the view of the professionals was aggregated to ascertain the perceived benefits of the green building initiatives, and it was revealed that enhancing occupants' comfort and health (MS=4.22) ranks first. Improving internal air quality, productivity and the occupants' satisfaction (MS=4.09) rank second, while creating new opportunities for other industries to benefit (MS=4.03) ranks third. These results suggest that the respondents believed that buildings should be constructed accounting for the importance of providing high-quality interior environments for all occupants and users. The present findings are in agreement with Dahiru et al. (2014), where it was affirmed that health and productivity gain was the most important benefit from green building construction.

Other important benefits were an innovation in the construction industry (MS=3.98), which ranked fourth, reduced aggregate future capital and maintenance costs, as well as creating and increasing job 
opportunities in the construction industry (MS=3.85), coming in fifth. Improving and protecting the eco-system maintaining the integrity of the environment $(\mathrm{MS}=3.83$ ) ranks seventh, while promoting technological exchange among countries $(M S=3.82)$ ranks eighth. These results indicate that the respondents' believe that green building initiative is an innovation towards ameliorating the negative impact of conventional buildings. Furthermore, the findings affirm the finding of Ramesh and Emran (2013) that "enhancing the comfort and health of occupant" (MS=4.22)," "reduced aggregate future capital and maintenance costs" (MS=3.85) and "reduced aggregate use of water and energy" (MS=3.52) are benefits that can be derived from green building development.

Table 4

Benefits of green building developments: Professional perspectives

\begin{tabular}{|c|c|c|c|c|c|c|c|}
\hline \multirow{2}{*}{ Benefit } & \multirow{2}{*}{$\begin{array}{c}\begin{array}{c}\text { Estate } \\
\text { Surveyors }\end{array} \\
\text { Mean } \\
\end{array}$} & \multirow{2}{*}{$\begin{array}{c}\text { Quantity } \\
\text { Surveyors } \\
\text { Mean } \\
\end{array}$} & \multirow{2}{*}{$\begin{array}{c}\text { Land } \\
\text { Surveyors }\end{array}$} & \multirow{2}{*}{$\begin{array}{c}\text { Architects } \\
\text { Mean }\end{array}$} & \multirow{2}{*}{$\begin{array}{c}\text { Builders } \\
\text { Mean } \\
\end{array}$} & \multicolumn{2}{|c|}{ Overall } \\
\hline & & & & & & Mean & Rank \\
\hline $\begin{array}{l}\text { Enhance the comfort and } \\
\text { health of the occupant }\end{array}$ & 4.21 & 4.00 & 4.02 & 4.78 & 4.11 & 4.22 & $1^{s t}$ \\
\hline $\begin{array}{l}\text { Improve internal air } \\
\text { quality, productivity and } \\
\text { occupants' satisfaction }\end{array}$ & 3.79 & 4.05 & 3.45 & 4.89 & 4.29 & 4.09 & $2^{n d}$ \\
\hline $\begin{array}{l}\text { Create new } \\
\text { opportunities for other } \\
\text { industries to benefit }\end{array}$ & 3.77 & 3.48 & 4.57 & 4.44 & 3.89 & 4.03 & $3^{r d}$ \\
\hline $\begin{array}{l}\text { Innovation in the } \\
\text { construction industry }\end{array}$ & 3.43 & 4.00 & 4.34 & 4.11 & 4.00 & 3.98 & $4^{\text {th }}$ \\
\hline $\begin{array}{l}\text { Reduced aggregate } \\
\text { future capital and } \\
\text { maintenance costs }\end{array}$ & 3.20 & 4.18 & 4.14 & 4.00 & 3.71 & 3.85 & $5^{\text {th }}$ \\
\hline $\begin{array}{l}\text { Create and increase job } \\
\text { opportunities in the } \\
\text { construction industry }\end{array}$ & 3.50 & 3.59 & 4.10 & 4.33 & 3.72 & 3.85 & $5^{\text {th }}$ \\
\hline $\begin{array}{l}\text { Improve and protect the } \\
\text { eco-system }\end{array}$ & 3.47 & 3.77 & 3.66 & 4.11 & 4.16 & 3.83 & $7^{\text {th }}$ \\
\hline $\begin{array}{l}\text { Promote technological } \\
\text { exchange among } \\
\text { countries }\end{array}$ & 3.88 & 2.74 & 3.39 & 4.44 & 4.63 & 3.82 & $8^{\text {th }}$ \\
\hline $\begin{array}{l}\text { Encourage upgrade and } \\
\text { integration of } \\
\text { professionals } \\
\end{array}$ & 3.69 & 3.61 & 3.57 & 4.22 & 3.89 & 3.80 & $9^{\text {th }}$ \\
\hline $\begin{array}{l}\text { Reduced greenhouse gas } \\
\text { and } \mathrm{Co}_{2} \text { emissions }\end{array}$ & 3.57 & 4.00 & 3.23 & 4.33 & 3.74 & 3.77 & $10^{\text {th }}$ \\
\hline $\begin{array}{l}\text { Create heathier and } \\
\text { more comfortable } \\
\text { building environment }\end{array}$ & 3.79 & 3.57 & 3.14 & 4.22 & 4.21 & 3.77 & $10^{\text {th }}$ \\
\hline $\begin{array}{l}\text { Conservation and } \\
\text { preservation of natural } \\
\text { resources }\end{array}$ & 3.79 & 3.48 & 3.64 & 4.22 & 3.68 & 3.76 & $12^{\text {th }}$ \\
\hline $\begin{array}{l}\text { Enhanced long-term } \\
\text { economic performance }\end{array}$ & 3.64 & 3.39 & 3.34 & 4.11 & 3.83 & 3.66 & $13^{\text {th }}$ \\
\hline $\begin{array}{l}\text { It powers the use of } \\
\text { renewable energy } \\
\text { technology }\end{array}$ & 3.50 & 3.86 & 2.91 & 4.11 & 3.88 & 3.65 & $14^{\text {th }}$ \\
\hline $\begin{array}{l}\text { Reduce operational cost } \\
\text { of building, }\end{array}$ & 3.07 & 3.65 & 3.83 & 3.67 & 3.82 & 3.61 & $15^{\text {th }}$ \\
\hline $\begin{array}{l}\text { Last longer and easy to } \\
\text { maintain }\end{array}$ & 3.60 & 3.70 & 2.52 & 4.33 & 3.80 & 3.59 & $16^{\text {th }}$ \\
\hline $\begin{array}{l}\text { Promote longer } \\
\text { economic life of building }\end{array}$ & 3.79 & 3.30 & 3.16 & 3.67 & 3.94 & 3.57 & $17^{\text {th }}$ \\
\hline $\begin{array}{l}\text { Reduce the aggregate } \\
\text { use of water and energy }\end{array}$ & 3.07 & 3.35 & 3.20 & 4.33 & 3.63 & 3.52 & $18^{\text {th }}$ \\
\hline Higher sale and lease & 3.43 & 3.39 & 2.98 & 4.11 & 3.61 & 3.50 & $19^{\text {th }}$ \\
\hline
\end{tabular}




\begin{tabular}{|c|c|c|c|c|c|c|c|}
\hline value & & & & & & & \\
\hline $\begin{array}{l}\text { Promote efficient use of } \\
\text { space }\end{array}$ & 3.47 & 3.22 & 3.00 & 3.81 & 3.56 & 3.41 & $20^{\text {th }}$ \\
\hline $\begin{array}{l}\text { Reduction in demolition } \\
\text { and construction waste }\end{array}$ & 3.50 & 2.74 & 2.11 & 4.00 & 3.79 & 3.23 & $21^{s t}$ \\
\hline $\begin{array}{l}\text { Expected high tenancy } \\
\text { rate }\end{array}$ & 3.40 & 3.57 & 2.52 & 3.78 & 2.63 & 3.18 & $22^{n d}$ \\
\hline $\begin{array}{l}\text { Reduced costs of capital } \\
\text { in administration, project } \\
\text { and property } \\
\text { management, } \\
\text { maintenance etc. }\end{array}$ & 3.71 & 2.26 & 3.45 & 3.11 & 3.18 & 3.14 & $23^{r d}$ \\
\hline Total Mean & 3.58 & 3.52 & 3.40 & 4.14 & 3.81 & 3.69 & \\
\hline
\end{tabular}

Source: Author's survey.

Knowledge of the hindrances to a successful implementation of green initiatives development will aid in identifying ways to promote sustainability in the built environment. It is important to understand the barriers that exist from the professionals' perspective to provide pragmatic solutions and recommendations to mitigate such barriers and expedite the growth of the sustainable construction industry. The barriers listed in the questionnaire were devised from the literature review. Table 5 illustrates the results of the respondent's perception towards the hindrance to green building development and ranked according to the mean value. This was done following the method adopted by Liu et al (2012). The results demonstrate that the top three most important barriers as considered by the respondents were "lack of awareness by developers" (MS=4.54), "Non-availability of local materials" (MS=4.06) and "No standard for structural control of green building" (MS=4.05).

This shows that a lack of awareness and standard control is present. The findings are in line with those of Williams and Dair (2007), where it was established that there is a need for regulation and a policy to keep pace with best practices. Conversely, the three barriers considered least important were "uncertain economic environment" (MS=3.52), "energy and environmental challenges" (MS=3.49) and "unsupportive environment" (MS=3.36). This could be attributed to the fact that green construction is a fairly new concept in Nigeria.

Table 5

Hindrances to green building developments: Professional perspectives

\begin{tabular}{|c|c|c|c|c|c|c|c|}
\hline \multirow[t]{2}{*}{ Hindrances } & \multirow{2}{*}{$\begin{array}{c}\begin{array}{c}\text { Estate } \\
\text { Surveyors }\end{array} \\
\text { Mean } \\
\end{array}$} & \multirow{2}{*}{$\begin{array}{c}\text { Quantity } \\
\text { Surveyors } \\
\text { Mean } \\
\end{array}$} & \multirow{2}{*}{$\begin{array}{c}\begin{array}{c}\text { Land } \\
\text { Surveyors }\end{array} \\
\text { Mean } \\
\end{array}$} & \multirow{2}{*}{$\begin{array}{c}\text { Architects } \\
\text { Mean }\end{array}$} & \multirow{2}{*}{$\begin{array}{r}\text { Builders } \\
\text { Mean }\end{array}$} & \multicolumn{2}{|c|}{ Overall } \\
\hline & & & & & & Mean & Rank \\
\hline $\begin{array}{l}\text { Lack of awareness by } \\
\text { developers }\end{array}$ & 4.92 & 4.26 & 4.57 & 4.33 & 4.61 & 4.54 & $1^{\text {st }}$ \\
\hline $\begin{array}{l}\text { Non-availability of local } \\
\text { materials }\end{array}$ & 3.50 & 4.87 & 2.84 & 4.30 & 4.80 & 4.06 & $2^{n d}$ \\
\hline $\begin{array}{l}\text { No standard for structural } \\
\text { control of the green } \\
\text { building }\end{array}$ & 3.50 & 4.09 & 4.11 & 4.00 & 4.57 & 4.05 & $3^{r d}$ \\
\hline $\begin{array}{l}\text { Lack of adequate } \\
\text { knowledge and technical } \\
\text { know-how by professionals } \\
\text { to handle the job }\end{array}$ & 3.79 & 4.43 & 4.52 & 3.88 & 3.58 & 4.04 & $4^{\text {th }}$ \\
\hline $\begin{array}{l}\text { Lack of interest in } \\
\text { sustainable building } \\
\text { development }\end{array}$ & 3.87 & 3.87 & 3.57 & 3.78 & 4.80 & 3.98 & $5^{\text {th }}$ \\
\hline $\begin{array}{l}\text { Lack of adequate research } \\
\text { on green building }\end{array}$ & 3.53 & 3.70 & 4.57 & 3.67 & 4.16 & 3.93 & $6^{\text {th }}$ \\
\hline $\begin{array}{l}\text { Lack of green building cost } \\
\text { and performance data }\end{array}$ & 3.47 & 3.43 & 4.61 & 3.88 & 4.00 & 3.88 & 7 th \\
\hline $\begin{array}{l}\text { High cost of imported green } \\
\text { building materials }\end{array}$ & 3.80 & 2.91 & 4.61 & 4.33 & 3.53 & 3.84 & $8^{\text {th }}$ \\
\hline Data challenges & 3.53 & 3.74 & 4.66 & 3.33 & 3.56 & 3.76 & $9^{\text {th }}$ \\
\hline $\begin{array}{l}\text { No enabling laws to } \\
\text { promote its development }\end{array}$ & 3.47 & 4.26 & 3.50 & 4.00 & 3.42 & 3.73 & $10^{\text {th }}$ \\
\hline
\end{tabular}


No market expectation for green building at present Divergent interests and views of professionals in built environment

High initial construction cost of green building Investors choose to remain simple.

Uncertain economic environment

Energy and environmental challenges

Unsupportive environment

Total Mean

\begin{tabular}{lllllll}
3.43 & 3.87 & 3.50 & 3.88 & 3.72 & 3.68 & $11^{\text {th }}$ \\
3.73 & 3.57 & 3.09 & 4.11 & 3.85 & 3.67 & $12^{\text {th }}$ \\
3.81 & 3.74 & 3.59 & 3.88 & 3.21 & 3.65 & $13^{\text {th }}$ \\
3.80 & 3.57 & 3.64 & 3.88 & 3.28 & 3.63 & $14^{\text {th }}$ \\
3.36 & 3.61 & 3.20 & 3.88 & 3.53 & 3.52 & $15^{\text {th }}$ \\
3.64 & 3.96 & 3.11 & 3.44 & 3.30 & 3.49 & $16^{\text {th }}$ \\
4.07 & 3.87 & 3.02 & 2.55 & 3.27 & 3.36 & $17^{\text {th }}$ \\
3.72 & 3.87 & 3.81 & 3.83 & 3.83 & 3.81 & \\
\hline
\end{tabular}

Source: Author's survey.

This study corroborates the findings of Ameh, et al. (2007) in Nigeria, where it was affirmed that built environment professionals are aware of sustainability principles, and sources of information on sustainable building practices are mostly drawn from personal research. However, a need for more sensitization to raise the level of awareness is recognized.

The present findings are in line with those of Dahiru et al. (2014), who argued that the lack of awareness, unsupportive environment, a lack of interest in sustainable building development and the economic situation are factors that militate against the practice of green building. The study also corroborates the findings of Dalibi et al. (2017), where it was noted that the perception of green building being expensive, the unavailability of local green building materials and other components, the high cost of imported green building materials, divergent interests and views among stakeholders are hindrances to green building development in the built environment.

\section{Conclusions}

This study presents the results of the data collected using a questionnaire. The purpose of the study is to assess the awareness and knowledge of deliberately selected professionals within the built environment regarding the adoption of green building initiatives. This is done to examine their perception of the benefits and hindrances of green developments. To measure how active the respondents were in the field of green construction, five professions that were prominent in the built environment in the study area were selected. To achieve the objectives, a questionnaire was administered; and a total of $87.54 \%$ completed questionnaires were retrieved and found to be valid for analysis. The data from the questionnaires were then organized and analyzed using SPSS software.

The results highlighted that the general awareness regarding the concepts of green building in Benin City remain very low among professionals. Therefore, a greater and more conscious effort is required to raise awareness which will in turn accelerate the growth, adoption, and implementation of green building concepts. It is important to convey the goals and benefits of green construction methods to individuals who are relevant to the construction sector in order to achieve successful implementation of sustainable construction projects. Thus, educating the relevant parties to raise awareness of the green concept is vital to overcoming several obstacles hindering the dissemination of sustainable practices, such as the lack of awareness and knowledge of these methods and their benefits.

\section{Limitations}

The definition of green building as used in this study was based on the ideas derived from the literature by the authors. However, this definition was not communicated to the survey participants. It is assumed that the participants will have a common interpretation of the definition of green building. Therefore, it is acknowledged that a third-party certification scheme that could guide the participants ensuring they have a common basis to answer the survey questions was not provided.

Seeing as how the study was carried out in Benin City, a fast-growing state capital in Nigeria, the results obtained cannot be entirely used to generalize the whole nation, but could raise the awareness and consciousness of stakeholders regarding green building initiatives in the country. As a result, it is 
recommended that future research be carried out to focus on each geopolitical zone of the nation, to reach a conclusion about the study subject.

\section{References}

Aggarwal, R. K., \& Markanda, S. (2013). Effect of greenhouse gases and human population in global warming. Huanjing Gongcheng Jishu Xuebao, 2(1), 13-16.

Alam, S., \& Haque, Z. (2016). Fundamental principles of green building and sustainable site design. International Journal of Management and Applied Science, 2(11), 1-5.

Ameh, O. J., Isijiola, S. J., \& Achi, F. O. (2007). Assessment of the Sustainability of Public Buildings in Lagos Nigeria. Construction Research Journal, 1(1), 46-54.

Bernard, H. R. (2002). Research methods in anthropology: Qualitative and quantitative approaches. 3rd Alta Mira Press; Walnut Creek, CA.

Chan, A. P. C., Darko, A., \& Ameyaw, E. E. (2017). Strategies for promoting green building technologies adoption in the construction industry - An international study. Sustainability (Basel), 9, 969. https://doi.org/10.3390/su9060969

Chan, A. P. C., Darko, A., Olanipekun, A. O., \& Ameyaw, E. E. (2018). Critical barriers to green building technologies adoption in developing countries: The case of Ghana. Journal of Cleaner Production, 172, 1067-1079. https:// doi.org/10.1016/i.jclepro.2017.10.235

Cresswell, J. W \& Plano Clark V.L (2011). Designing and conducting mixed method research. 2nd Sage; Thousand Oaks, CA.

Cryer, B., Felder, J., Matthews, R., Pettigrew, M., \& Okrent, B. (2006). Evaluating the diffusion of green building practices. Applied management research project fall 2005/Winter 2006. UCLA Anderson School of Management

Dahiru, D., Dania, A. A., \& Adejoh, A. (2014). An investigation into the prospects of green building practice in Nigeria. Journal of Sustainable Development, 7(6), 158-167. https://doi.org/10.5539/jsd.v7n6p158

Dalibi, S. G., Feng, J. C., Shuangqin, L., Sadiq, A., Bello, B. S., \& Danja, I. I. (2017). Hindrances to green building developments in Nigeria's built environment: "The project professionals' perspectives". International Conference on Environmental and Energy Engineering. IOP Publishing IOP Conf. Series: Earth and Environmental Science 63:012-033. https:// doi.org/10.1088/1755-1315/63/1/012033

Darko, A., Chan, A. P. C., Owusu-Manu, D.-G., \& Ameyaw, E. E. (2017). Drivers for implementing green building technologies: An international survey of experts. Journal of Cleaner Production, 145, 386-394. https://doi.org/10.1016/i.jclepro.2017.01.043

Durmus-Pedini, A., \& Ashuri, B. (2010). An overview of the benefits and risk factors of going green in existing buildings. International Journal of Facility Management, 1(1), 1-15.

Edeoja, J. A., \& Edeoja, A. O. (2015). Carbon emission management in the construction industry - Case studies of the Nigerian construction industry. American Journal of Engineering Research, 4(7), 112122.

Ezema, I. C., Opoko, A. P., \& Oluwatayo, A. A. (2016). De-carbonizing the Nigerian housing sector: The role of life cycle $\mathrm{CO}_{2}$ assessment. International Journal of Applied Environmental Sciences, 11(1), 325-349.

Giwa, S. O., Sulaiman, M. A., \& Nwaokocha, C. N. (2017). Inventory of Greenhouse Gases Emissions from Gasoline and Diesel Consumption in Nigeria. Nigerian Journal of Technological Development, 14(1), 1-12. https:// doi.org/10.4314/njtd.v14i1.1

Gunnell, K. (2009). Green building in South Africa: Emerging trends. Paper prepared for Department of Environmental Affairs and Tourism (DEAT), Directorate. https://www.academia.edu/29569417/Green_Building_in_South_Africa_Emerging_Trends.

Ishan, G. K., Ankush, A. P., \& Shruti-Mrudula, N. W. (2014). Sustainable construction: Green building concept - A case study. International Journal of Innovative and Emerging Research in Engineering, 2(2), $59-65$.

Lam P. T. I., Chan E. H. W., Chau, C. K., Poon, C. S., \& Chun, K. P. (2009). Integrating Green Specifications in Construction and Overcoming Barriers in Their Use. Journal of Professional Issues in Engineering Education and Practice, 135, 142-152. https://doi.org/10.1061/(ASCE)1052$\underline{3928(2009) 135: 4(142)}$ 
Liu, J.Y., S.P. Low, \& X. He (2012). Green practices in the Chinese building industry: drivers and impediments. Journal of technology management in China, 7(1):50-63. https://doi.org/10.1108/17468771211207349

Love, P. E. D., Niedzweicki, M., Bullen, P. A., \& Edwards, D. J. (2012). Achieving the green building council of Australia's world leadership rating in an office building in Perth. Journal of Construction Engineering and Management, 138, 652-660. https://doi.org/10.1061/(ASCE)CO.1943-7862.0000461

Masrom, M. A. N., Rahim, M. H. I. A., Ann, S. C., Mohamed, S., \& Goh, K. C. (2017). A preliminary exploration of the barriers of sustainable refurbishment for commercial building projects in Malaysia. Procedia Engineering, 180, 1363-1371. https://doi.org/10.1016/j.proeng.2017.04.299

Matthew, O., Osabohien, R., Fasina, F., \& Fasina, A. (2018). Greenhouse gas emissions and health outcomes in Nigeria: Empirical insight from auto-regressive distribution lag technique. International Journal of Energy Economics and Policy, 8(3), 43-50.

Matthew, O., Osabohien, R., Olawande, T., \& Urhie, E. (2019). Manufacturing industries and construction emissions in Nigeria: Examining the effects on health conditions. International Journal of Civil Engineering and Technology, 10(1), 2401-2414.

Mehta, G., Mehta, A., \& Sharma, B. (2014). Selection of materials for green construction: A review. IOSR Journal of Mechanical and Civil Engineering, 11(6), 80-83. https://doi.org/10.9790/1684$\underline{11638083}$

Ojo, B., Oyetunji, B. O., \& Oyetunji, A. K. (2018). Barriers to ICT deployment in the Nigerian real estate practice. FULafia Journal of Science \& Technology, 4(2), 57-65.

Okafor, B. N. (2016). Green building for Nigeria public institutions towards effective administration of public properties: A case study of military barracks and police stations in Anambra State, Nigeria. International Journal of Physical and Human Geography, 4(2), 16-22.

Potbhare, V., Syal, M., \& Korkmaz, S. (2009). Adoption of green building guidelines in developing countries based on U.S. and India experiences. Journal of Green Building, 4(2), 158-174. https://doi.org/10.3992/igb.4.2.158

Ramesh, S. P., \& Emran, K. M. (2013). Energy efficiency in green buildings - Indian concept. International Journal of Emerging Technology and Advanced Engineering, 3(3), 329-336.

Sagheb, A., Vafaeihosseini, E., \& Ramancharla, P. K. (2011). The role of building construction materials on global warming: lessons for architects. In: National Conference on Recent Trends in Civil Mechanical Engineering. Report No: IIIT/TR/2011/-1. India

Simpeh, E. K., \& Smallwood, J. J. (2015). Factors influencing the growth of green building in the South African Construction Industry. Proceedings of the Smart and Sustainable Built Environment (SASBE), Netherlands held on the $9^{\text {th }}$ - 11 $1^{\text {th }}$ Dec 2015.

Simpeh, E. K., \& Smallwood, J. J. (2018). Analysis of the benefits of green building in South Africa. Journal of Construction Project Management and Innovation, 8(2), 1829-1851.

Tathagat, D., \& Dod, D. R. (2015). Role of green buildings in sustainable construction - Need, challenges and scope in the Indian scenario. Journal of Mechanical and Civil Engineering, 12(2), 1-9.

Uwazie, U. I., Igwemma, A. A., \& Okonkwo, N. O. (2015). Sustainable development in the Nigerian housing sector: Challenges and opportunities for achieving the green initiative. International Journal of African and Asian Studies., 12, 41-49.

Williams, K., \& Dair, C. (2007). What is stopping sustainable building in England? Barriers experienced by stakeholders in delivering sustainable developments. Sustainable Development (Bradford), 15(3), 135-147. https:// doi.org/10.1002/sd.308

Wu Z, Jiang M, Cai Y, Wang H, Li S. (2019). What Hinders the Development of Green Building? An Investigation of China. Int J Environ Res Public Health. 28;16(17):3140. https://doi.org/10.3390/ijerph16173140

Zhang, X., Platten, A., \& Shen, L. (2011). Green property development practice in China: Costs and barriers. Building and Environment, 46, 2153-2160. https://doi.org/10.1016/j.buildenv.2011.04.031 